\title{
Redistributing Income through Pricing Policies
}

\author{
James Cox
}

7 He pricing policies of public enterprises and other government agencies that sell goods and services to the public can be used to redistribute income.

Such policies are the main, if not the only, technique of redistribution open to State and local governments, which are not able to use the Commonwealth's income tax and social security arrangements.

Such pricing policies enable governments to promote significant and widely supported social objectives such as ensuring that the disadvantaged can pay their energy and water bills and have access to public transport (the author vividly recalls being told how important travel concessions are for the mentally ill in New South Wales). Nevertheless, such subsidies may be an inefficient method of redistribution because they are tied to the consumption of particular goods and services: persons who do not have ready access to the service are unable to benefit from the associated subsidy. For example, public transport subsidies are of little benefit to disabled people who are unable to use public transport.

Pricing policies are coming under pressure, largely from government moves to expose their enterprises to greater competition and to make social policy more equitable and transparent. As well, in recent years progress has been made in reducing cross-subsidies that do not have a clear social purpose (see, for example, Govermment Pricing Tribunal, 1994). Equally, obstacles to change arise from poor Commonwealth-State relations (which limit the options that are practically available to State governments), the absence of a vocal constituency outside government to support some changes, and suspicion by the recipients of subsidies about the purposes of governments that propose changes.

\section{The Nature and Purpose of Subsidies}

A subsidy is a service provided to a group of recipients at a price below the cost of production of the service. A subsidy is therefore a form of support for those who purchase a particular good or service.

James Cox is Principal Adviser to the NSW Government Pricing Tribunal. In 1989 and 1990 he conducted for the New South Wales government a review of the concessions on prices that the government offers to pensioners and some other groups. This article does not discuss the conclusions and recommendations of the review but draws on material that was collected for the review. 
A subsidy can be provided in a number of ways:

- Cash assistance earmarked for a particular purpose, such as government contributions towards paying electricity bills.

- Subsidies paid directly to service providers, such as payments to bus companies to enable them to carry students to and from school free of charge.

- Cross-subsidies within the pricing structure of an enterprise, as when electricity customers in remote areas are subsidised by other customers.

- Revenue forgone from granting tax concessions, such as motor vehicle tax concessions for pensioners.

- The acceptance by an organisation of a less-than-commercial rate of return. In some cases the service may run at a deficit, thus requiring supplementation from the general revenue of the State. Examples include the ambulance service and dental treatment for Commonwealth health-card holders and schoolchildren.

Subsidies are provided to individuals, non-profit organisations, for-profit enterprises, public enterprises and government departments. They are financed from the general revenue of the State or through the pricing structure of particular enterprises.

A commercial organisation might choose to provide subsidies in order to attract customers or because a pricing structure that reflected true costs would place too high a burden of complexity on the organisation and its customers. But large crosssubsidies are unlikely to persist in competitive markets. Our concern is with the element of subsidy that is in excess of what a firm would choose to provide on commercial grounds.

Governments frequently use public enterprises to advance non-commercial objectives, known as the 'community service obligations' (CSOs) of the enterprise. (In New South Wales these are in future to be referred to as 'social policies' of the government that are delivered through enterprises.) A subsidy that is intended to benefit a particular group of users of a service rather than users in general is frequently referred to as a 'concession'.

Where subsidies are paid directly from the government's budget, reliable information can be obtained about how much they cost and who benefits from them. Where subsidies are provided in less transparent ways, substantial conceptual and practical difficulties often arise that must be addressed before the amount and distributional impact of the subsidy can be estimated.

The NSW government aims to move gradually to a situation where the provision of subsidies by government business enterprises is governed by contracts between the government and the enterprise. The amount of the subsidy would then be negotiated between the enterprise and its sponsoring department on the one 
hand, and the Treasury on the other. The negotiation process should result in better information about the true cost of subsidies.

\section{The Costs of Subsidies}

The cost of a subsidy must be distinguished from its value to recipients. The 'cost' is the opportunity cost of the resources that are consumed in providing the subsidy. The 'value' is the amount that recipients would be prepared to pay rather than be deprived of the subsidy.

In practice, estimates are usually made of the costs to government, rather than to society as a whole, of providing subsidies. The cost to government of a subsidy provided by a public enterprise or a government department is the revenue that is forgone (assuming unchanged behaviour by the recipients) by charging a concessional rather than a market price, minus any revenue that is generated by serving the additional demand which results from charging the concessional price, plus the additional cost involved in serving the additional demand. Consider the cost to government of providing public-transport concessions to pensioners during the period between the daily weekday peaks. Because most of the costs of capital and labour are required to meet the peak demand, the additional cost of carrying these passengers is likely to be low. (This is less true of services provided during the evenings or at weekends.) The low concessional fares are likely to generate some extra travel. And the relevant 'commercial' fare for comparison is an off-peak rather than a full fare. The net cost to government of providing these concessions may not be great.

The cost to government of a subsidy provided to a private organisation or an individual depends on the rules governing the subsidy. The private organisation will gain the revenue from the subsidy along with additional revenue from customers from serving the additional demand. It will also pay the additional costs of serving that demand.

The way in which a subsidy is granted can have an effect on demand. A reduction in a per-unit price for electricity and water, for example, is likely to be more effective than a reduced access charge in increasing demand. A subsidy that is paid directly to individuals is likely to be more effective in increasing demand than one that is paid to a welfare organisation to which individuals must then apply for assistance.

Revenue forgone involves a transfer between the provider of the subsidy and the recipients. The subsidy must be financed either from the general revenue of the State or by ligher prices than otherwise for some other customers of the enterprise. Either course of action is likely to result in distortions to the allocation of resources.

Estimates of revenue forgone are relatively straightforward in principle. In practice, they may require detailed information that is not always available. For example, pensioners are able to travel over much of Sydney's public transport network if they purchase a one-dollar excursion ticket. The appropriate market fare comparator may be unclear unless detailed information is recorded concerning the use that pensioners make ol the excursion ticket. 
Estimates of the demand effects of subsidies require knowledge of the relevant detailed elasticities of demand. For example, the demand for excursion travel by pensioners in Sydney may be far more elastic than travel by commuters. These detailed elasticities may not be readily available. Views differ about the appropriate concept of cost. Short- or long-term marginal cost may be preferred, depending on the context. And some argue that a share of fixed costs should be allocated to the subsidised service. This may be sensible if the subsidised demand is a large component of the total demand.

It is important to be clear about which concept of cost is being employed in a particular context. In practice, most estimates of the cost of subsidies relate to revenue forgone. Estimates of cross-subsidies in electricity and water are usually based on assumptions about the allocation of both fixed and variable costs.

The NSW Budget includes information about 'budget funded concessions' (New South Wales Government, 1994:5-140-5-144). These services are described as 'provided free or at less than the normal charge to a specific eligible class of individuals or other entities'. Only those concessions that are funded from the budget (whether through direct expenditure or tax concessions) are included in the list.

The information in the budget papers is summarised in Table 1, which presents estimates of the revenue forgone from concessions. Payments to public and private transport operators make up about two-thirds of budget-funded concessions.

A more complete accounting of concessional expenditure for 1988/89 was undertaken as part of a review for the NSW government. This review considered offbudget subsidies (such as cross-subsidies) as well as on-budget ones. Concessional expenditure on this basis in $1988 / 89$ amounted to $\$ 1,637 \mathrm{~m}$. These figures are estimates of revenue forgone (except for cross-subsidies, which were estimated on a fully distributed cost basis). There are some important omissions because of the absence of data (for example, on cross-subsidies within the pricing structure of electricity distributors).

Tables 2 and 3 present summary information on the sources of finance of these subsidies, the means of distribution and the beneficiaries. The main source of finance is the NSW government, though the Commonwealth government, local government and the customers of public enterprises also make contributions. Only about one-quarter of concessional expenditure was distributed in the relatively transparent forms of cash payments to individuals and explicit subsidies to service providers.

Table 3 demonstrates that around three-quarters of concessional expenditure is directed to five groups: pensioners and senior citizens, tenants in public housing, students and schoolchildren, low-income persons generally (including pensioners), and home owners in the Sydney region.

\footnotetext{
I Cross-subsidies so measured may not be subsidlies in the strict economic sense because price may exceed marginal cost. But, as noted, many of these cross-subsidies would be modified if the agency providing them became subject to competition. Readers who object to adding estimates of crosssubsidies to estimates of revenue forgone may prefer to ignore the totals in Tables 1-3.
} 


\section{Table 1}

\section{Budget funded concessions in New South Wales, 1994/95}

\begin{tabular}{|c|c|c|}
\hline Budget concessions & & $\$ m$ \\
\hline $\begin{array}{l}\text { Education } \\
\text { Energy }\end{array}$ & $\begin{array}{l}\text { Transport of disabled children, TAFE fee exemptions } \\
\text { Power supply in remote areas, assistance with bills to } \\
\text { disadvantaged }\end{array}$ & $\begin{array}{r}37.0 \\
10.2\end{array}$ \\
\hline Local Government & State's share of rate rebates & 52.0 \\
\hline Health & Mainly dental and ambulance services & 133.2 \\
\hline Total & & 232.4 \\
\hline Taxation concessions & & \\
\hline $\begin{array}{l}\text { Roads \& Traffic } \\
\text { Authority }\end{array}$ & $\begin{array}{l}\text { Drivers' licence concessions to pensioners } \\
\text { Motor vehicle tax concessions to pensioners } \\
\text { Other }\end{array}$ & $\begin{array}{r}23.6 \\
85.2 \\
6.0\end{array}$ \\
\hline Total & & 114.8 \\
\hline Payments to enterpris & ses & \\
\hline $\begin{array}{l}\text { Energy } \\
\text { Land \& Water }\end{array}$ & Pensioner concessions, grants to rural councils & 5.9 \\
\hline $\begin{array}{l}\text { Conservation } \\
\text { Planning \& Housine }\end{array}$ & $\begin{array}{l}\text { Mainly contributions to maintenance of irrigation schemes } \\
\text { Mainly rate rebates for pensioners }\end{array}$ & $\begin{array}{l}14.1 \\
70.1\end{array}$ \\
\hline$S R A^{*} \&$ STA ${ }^{* *}$ & $\begin{array}{l}\text { Low fares in general } \\
\text { Concessions to pensioners, unemployed, students } \\
\text { Operating losses on SRA passenger services } \\
\text { Operating losses on freight services } \\
\text { Other }\end{array}$ & $\begin{array}{r}137.0 \\
285.6 \\
36.3 \\
129.9 \\
6.2\end{array}$ \\
\hline Private Transport & Concessions to pensioners and students & 24.0 \\
\hline Operators & $\begin{array}{l}\text { Student concessions } \\
\text { Other }\end{array}$ & $\begin{array}{r}254.7 \\
20.9\end{array}$ \\
\hline Total & & 984.7 \\
\hline Grand total & & 1331.9 \\
\hline
\end{tabular}

"State Rail Authority of NSW. "*State Transit Authority of NSW.

Source: NSW Budget Papers, 1994/95. 
Table 2

Concessional expenditure in 1988/89: sources and uses of finance

\begin{tabular}{|lr|}
\hline Sources of finance & $\$ m$ \\
& \\
State government & 1217 \\
Commonwealth government & 85 \\
Local government & 41 \\
Customers of public enterprises & 288 \\
Other & 6 \\
& \\
Total & 1637 \\
\hline & \\
Means of distribution & \\
& \\
Cash payments (e.g. isolated patients' travel and accommodation) & 32 \\
Payments to service providers (e.g. to private bus companies) & 365 \\
Deficit finance (e.g. State Rail Authority) & 455 \\
Cross-subsidies (e.g. electricity, water) & 279 \\
Revenue forgone (e.g. rent rebates, tax concessions) & 507 \\
& \\
Total & 1637 \\
\hline
\end{tabular}

\section{Table 3}

\section{Beneficiaries of concessional expenditure in 1988/89}

\begin{tabular}{|llr|}
\hline Beneficiaries & Help provided & Estimated cost $(\$ \mathrm{~m})$ \\
Pensioners and senior citizens & $\begin{array}{l}\text { Rate and utility rebates } \\
\text { and travel concessions }\end{array}$ & \\
& Travel concessions & 343 \\
Unemployed & & 23 \\
Low income generally & & \\
(including pensioners and & Legal aid, dental, ambulance & 175 \\
unemployed) & Rent rebates & 307 \\
Public tenants & Home care services & 89 \\
Frail aged and disabled & Travel concessions & 245 \\
Students and schoolchildren & 161 \\
Sydney home owners & Water board cross-subsidies \\
Residents of country towns & Water and sewerage subsidy & 66 \\
Electricity customers outside & Subsidies & 49 \\
Sydney & & 179 \\
Others & & 1637 \\
Total & & \\
\hline
\end{tabular}

Source for Tables 2 and 3: author's calculations based on information provided by NSW government agencies. Entries may not sum to totals due to rounding. 


\section{Who Benefits from Concessions?}

As noted, the value of a subsidy is the maximum amount a person would pay to retain the benefit (SWPS, 1984:26). If behaviour is unchanged, this amount equals the additional amount the person would have to pay to purchase the same quantity of service at market rather than concessional prices. Many people would, however, purchase less of the service if a market rather than a concessional price were charged. Because they would purchase less of the now more expensive service, the loss to this group would be less than the additional amount required to purchase the same amount of the service at the higher price.

As part of the 1989 inquiry, the NSW Cabinet Office commissioned a study of the value of a selected group of concessions to recipients (King \& Manning, 1989). The concessions selected for study were for council and water rate payments, energy, car ownership, public transport fares, and health services such as dental and ambulance services. The basis of the study was the then most recent ABS income distribution survey for 1986 . This income distribution was updated to 1988-89 using micro-simulation techniques. The population eligible for the concessions was then estimated from the updated income distribution on the basis of conditions for eligibility; for example, the number of people who qualified for one of the relevant Commonwealth health cards. The number of eligible people using services on which concessions are granted, and the extent of their use of these services, were estimated from Household Expenditure Survey data. Finally, the value of the concession for each episode of use was imputed on the assumption of unchanged behaviour.

The results of this exercise are summarised in Tables 4 and 5 for pensioner income units. Although some non-pensioner groups such as unemployment beneficiaries are eligible for some of these concessions, they do not appear to benefit greatly from them. The effect of home-ownership is shown in Table 4. This table shows that the majority of pensioner income units who owned or were purchasing their homes obtained a benefit of over $\$ 12$ a week from the selected concessions. By contrast, the majority of pensioner income units who were not home owners or home purchasers obtained a benefit of less than $\$ 8$ a week from concessions. Pensioners who are home owners are likely to have been richer over their adult lifetimes than pensioners who rent or board.

The effect of motor velicle ownership and access to public transport is shown in Table 5. Because of data limitations, the value of public-transport concessions was assumed to equal a set amount for pensioners who use public transport. This amount was lower for pensioners who own a car than for those who do not. The benefit from concessions is clearly greater for pensioners who own a car or are able to use public transport. The better-off pensioners are the most likely to own cars. And healthy people in well-established areas of Sydney are more likely to have good access to public transport than the disabled or those who live in outer suburbs or non-metropolitan areas.

2

Copies of this study are available from the present author on request. 


\section{Table 4}

\section{Estimated total value of selected NSW concessions by housing tenure, 1988/89}

\begin{tabular}{|lccccc|}
\hline \multicolumn{5}{|c|}{ Value to pensioner income units ('000s) per week } \\
Housing tenure & Under $\$ 4$ & $\$ 4-\$ 8$ & $\$ 8-\$ 12$ & Over $\$ 12$ & Total \\
\hline $\begin{array}{c}\text { Home owners/ } \\
\text { purchaser }\end{array}$ & 13.8 & 36.2 & 108.9 & 193.8 & 352.7 \\
\hline $\begin{array}{c}\text { Others (renters, } \\
\text { boarders etc.) }\end{array}$ & 84.1 & 49.1 & 81.1 & 0 & 214.3 \\
\hline
\end{tabular}

Source: King \& Manning (1989: tables 4.15(e) \& 4.15(f)). Entries may not sum to totals due to rounding.

\section{Table 5}

\section{Estimated total value of selected NSW concessions by use of transport concessions, 1988/89}

\begin{tabular}{|c|c|c|c|c|c|}
\hline \multirow[b]{2}{*}{ Transport mode } & \multicolumn{5}{|c|}{ Value to pensioner income units ('000s) per week } \\
\hline & Under \$4 & $\$ 4-\$ 8$ & $\$ 8-\$ 12$ & Over $\$ 12$ & Total \\
\hline$M V^{\star}$ only & 22.7 & 67.2 & 53.6 & 76.9 & 220.4 \\
\hline $\mathrm{PT}^{\star \star}$ only & 0 & 0 & 62.9 & 70.3 & 133.4 \\
\hline Both $M V$ and $\mathrm{PT}$ & 0 & 0 & 24.8 & 46.2 & 71.1 \\
\hline Neither MV nor PI & T 75.2 & 18.1 & 48.8 & 0 & 142.0 \\
\hline
\end{tabular}

"Motor vehicle. ${ }^{* *}$ Public transport.

Source: King \& Manning (1989: tables 4.17(c-f)). Entries may not sum to totals due to rounding. 


\section{Public Interest Explanations of Subsidies}

Do these subsidies achieve their purpose? This question raises the prior one of the purpose of the subsidies. As with theories of government regulation, the distinction between the 'public interest' and the 'private interest' explanations for subsidies (Stigler, 1975) is useful. The public interest explanation focuses on whether subsidies advance widely supported objectives such as economic efficiency and equity. The private interest explanation, in contrast, focuses on the benefits that subsidies deliver to influential groups, including decision-makers and organised special interests. These explanations are not mutually exclusive, but analysing their relative importance may provide some insight into the likely future development of subsidies.

Because of the availability of information from the 1989 review, the analysis offered here focuses on the concessions that are provided to pensioners and some other groups. But its results are likely to hold true for subsidies generally.

The public interest explanation suggests that concessions should be evaluated in terms of the following questions: Does the assistance advance important social objectives? Is it provided equitably? Is the assistance provided so as to minimise the sacrifice of society's other objectives (such as economic efficiency) that may be involved? Is sufficient information about the concession published to make it easy for policy-makers and the general public to weigh its benefits against the costs?

As already observed, important social objectives are advanced through concessions and subsidies generally. Subsidies also generate indirect benefits that need to be taken into account. For example, public-transport concessions may discourage the use of roads, with favourable consequences for safety, congestion and pollution. And subsidies to bus companies for the carriage of schoolchildren may be paid in return for (among other things) frequent services out of peak hours. Nevertheless, serious problems arise because assistance is tied to a particular service.

- Subsidies are frequently poorly targeted. Pensioners who rent or board receive fewer benefits from concessions than home-owning pensioners who tend to be wealthier.

- Inequities exist, for example between those with and those without good access to public transport.

- Some expenditure may be subsidised that is of little value to the recipient and society. Because fares are so cheap, pensioners may undertake some travel that is of little value to them. (The distinction between average and marginal effects is relevant here: not all travel by pensioners on excursion tickets is of little value.) By contrast, some higher valued travel (by taxi, for example) may not take place because of the absence of subsidy.

- Subsidies to individuals and private businesses are made from the budget and are highly transparent. Subsidies provided through the pricing policies of public 
enterprises have been fiunded in a less transparent manner. This makes it hard to compare the costs and benefits of particular programs of this type.

- Australian governments are committed to opening up previously monopolistic industries, including many public enterprises, to greater competition. Certain forms of subsidy (such as cross-subsidy and deficit finance) are inconsistent with competition or limit it. These forms of subsidy may need to be phased out or replaced by budget-financed subsidies.

- The cost of services provided by public enterprises may become excessive if subsidies are available. This is particularly true where the government is expected to meet the deficit of a loss-making service. Governments would become subject to a useful discipline if they were required to provide subsidies only through explicit contracts with the relevant enterprises.

- Subsidies have to be financed. State taxes are levied on a narrow base and are often regressive. An increase in the tax rate may well have unfavourable consequences for both equity and efficiency. Cross-subsidies within the pricing structure of public enterprises can also have adverse consequences (for example, if those who are overcharged reduce their use of the service, go out of business or relocate).

- There is duplication and lack of coordination in the provision of assistance both between Commonwealth and State agencies and within Commonwealth and State government administration.

This is a daunting list of problems. Two main conclusions seem to emerge. First, equity problems arise because assistance is tied to the provision of particular goods and services. Second, if assistance must be provided in this way, then it is best governed by a clear, contractual agreement that would be available to potential competitors and is financed from the budget. (The second point is taken up below; the first point is considered here.)

It is not hard to think of arrangements that would be fairer than the present ones. For example, pensioner concessions could be replaced by cash payments of an equal average amount that would be provicled to eligible recipients regardless of whether they are home owners or car owners or have good access to public transport. The new system could be introduced on an optional basis so as to ensure that those who do well from the present concessions can continue to enjoy them. Alternatively (or additionally), the present arrangement could be retained for existing pensioners and the new arrangements could be introduced for future recipients. While such possibilities are well-known to governments, the fact remains that even reforming governments (such as the present Victorian government) have not chosen to introduce them. This suggests that something in addition to 'public interest' factors has been at work. 


\section{Private Interest Explanations}

The alternative, private interest, explanation draws our attention to the incentives facing decision makers. Politicians and service providers may usefully be considered separately.

Politicians. Politicians may wish to promise subsidies to certain groups to build support in an attempt to gain or retain office. Because building support costs time and money, attention is most likely to be directed to well-organised groups whose members are thought likely to cliange their votes. The private interest explanation predicts that such groups are most likely to be favoured by subsidies. It also suggests that the subsidy system is likely to be most highly developed in those jurisdictions where competition between political parties has been fiercest (with many close elections), and least developed in jurisdictions where one political party has enjoyed long periods of electoral dominance. This is because the perceived rewards from offering additional subsidies are greatest when elections are closely contested.

The argument that pensioner concessions have something to do with election canpaigns is plausible in the light of the historical development of concessions. The first State government concessions were introduced in New South Wales around the turn of the century. They included a State pension, legal aid and dental services. Public-transport concessions were introduced in 1941 and concessions have developed since then on an uncoordinated basis, often to satisfy short-term political ends. Many concessions have resulted from election promises: for example, the rent rebate (1972), electricity rebates (1979), drivers' licence concessions (1979), the free ambulance service (1981), vehicle registration concessions (1984) and the senior-citizen travel concession (1988). The victorious Labor party offered some extension of transport concessions in the 1995 election campaign.

New South Wales provides more generous concessions to pensioners than to other, no less needy, groups such as the unemployed. For example, King and Manning (1989:60) showed that aged couples received an average amount of $\$ 13.55$ a week in 1988/89 from selected concessions if they were home-owners and $\$ 6.71$ a week from the same concessions if they were not. The corresponding figures for unemployment and sickness beneficiaries were $\$ 1.51$ a week and 90 cents a week. This discrepancy between pensioners and beneficiaries is consistent with the predictions of the private interest theory. By comparison with unemployment beneficiaries, pensioners are well-organised. (The author remembers being told in 1989 that there are no organised groups that can speak specifically for the unemployed. By contrast, the Combined Pensioners' Association has often been influential in the development of policy on concessions.) Pensioners are more likely than unemployed beneficiaries to live in marginal electorates and (it is thought) to change their votes. And pensioners tend to attract more public sympathy than the unemployed.

By comparison with Queensland (which, at least until recently, has enjoyed long periods of political stability), New South Wales provides a wider range of concessions and more generous concessions to pensioners. This, once again, is consistent with a private interest explanation of concessions. 
The evidence clearly suggests that competition between political parties has been important in the development of concessions. Because State governments have not had access to the broadly-based taxation and transfer arrangements that are reserved to the Commonwealth, providing subsidised services is one of the few ways in which they can show their concen for the interests of particular groups such as pensioners. To the extent that this is true, the argument that pensioner concessions make for poor social policy misses the point. Indeed, it has been suggested to the author that, even if such concessions were to be replaced by some more equitable arrangements, they would be reintroduced at the subsequent election.

Service providers. According to theorists of bureaucracy (such as Niskanen, 1971) assistance will tend to be provided in ways that increase the demand for subsidised service providers. This will encourage expansion of agencies, which will, in turn, lead to higher salaries and more jobs. And a reduction in the demand for a service may lead to higher subsidies rather than to a reduction in the quantity of the service that is offered to the market.

Two kinds of evidence exist that support the claim that subsidies have (at least in the past) been provided in ways that tend to increase the demand for particular service providers. First, there is little competition for the subsidised demand. Cash payments (which recipients can use to buy services from any of a number of providers) are unusual. Contractual arrangements between governments and competing providers are also uncommon, although they may become more common. Instead, subsidies tend to be paid to monopoly public enterprises or to private companies that have a local monopoly (such as private bus companies). Second, the form in which some subsidies are provided may lead to greater use of the service in question. For example, the demand by pensioners for off-peak travel is likely to some extent to be responsive to the fare charged. By contrast, concessions that are granted on the access component of charges (such as for Sydney Water) are less likely to increase demand. Both types of subsidy exist in New South Wales, but the former type is more important than the latter because it includes the most expensive subsidies, such as for transport, dental and ambulance services, and public transport.

In conclusion, there are important private interests that support continuation of the present concession system even if, in principle, better ways exist to advance the government's social objectives.

\section{Future Prospects}

With its commitment to the idea of the 'fair go', Australia is likely to continue with policies to redistribute income to the disadvantaged. But these policies are coming under increasing challenge because of concern about the adverse effects of the taxation that finances the programs and competition from countries (including Asian ones) with less extensive welfare states than Australia's. The lesson to be learned here is a subtle one (see Cox, 1993, for further discussion). It is not that social policies should be abandoned; the social harmony resulting from successful imple- 
mentation of such policies will assist in making Australia an attractive place in which to work and invest. Rather, it is that social policies should be confined to those things that government can do best and that those policies should be implemented as efficiently as possible.

Governments' desire to minimise expenditure and reduce costs to business will generate pressure to change the subsidies that have been discussed here. Indeed, this is already happening. For example, the benefits of productivity improvements in the electricity and water industries in New South Wales have been passed on in recent years to business rather than household customers, thus partly redressing the over-charging of business in the past. This policy direction is likely to continue under the present Carr Government. And other States are following.

The concessions provided on social policy grounds to pensioners, the unemployed, students and so on will not be greatly affected by the phasing out of the cross-subsidy from business to household customers. Eligibility for many State government concessions is dependent on possession of a Commonwealth health card. The pressures referred to earlier may lead to a redefinition of eligibility for Commonwealth benefits, leading to corresponding clianges in State government benefits.

Gradually increasing competition in areas such as electricity will make it increasingly necessary to make subsidies that are at present received by particular providers generally available to all providers. Because of this, and the desire for greater transparency, subsidies are increasingly likely to take the form of explicit contractual agreements between government and suppliers. The NSW government's social programs policy (New South Wales Treasury, 1994) is a good example of this. This greater transparency is likely to encourage greater scrutiny of the costs and benefits of concessions, which may well be modified at the margin. For example, governments could choose not to increase the less important concessions in line with inflation.

It is less certain that governments will redress the inequities which arise from tying assistance to consumption of particular goods and services. Analyses such as the present one may encourage clianges by drawing attention to the unfairness of the present arrangements. State governments may be able to reduce some inequities; for example, by reducing the difference between public and private bus travel subsidies to pensioners. A more effective way of addressing the unfairness of the present arrangements would be to introduce a supplementary program (such as a cash payment) for those who do not obtain much benefit from the present arrangements. Such a supplementary program would be difficult to introduce, requiring as it does agreement between the Commonwealtlı and the States. And it would be of little political benefit because it would assist powerless (and sometimes unpopular) groups. Such a program seems unlikely to be introduced at a time when governments are concerned to restrain their expenditure. 


\section{References}

Cox, J. (1993), 'Are There Better Ways to Achieve Distributional Objectives?', Economic Papers 12(3):11-21.

Government Pricing Tribunal of NSW (1994), Annual Report 1993-94, Sydney.

King, A. \& I. Manning (1989), The Incidence of State Concessions in New South Wales, A Report to the Cabinet Oflice of New South Wales, National Institute of Industry and Economic Research, Melboune.

New South Wales Govenment (1994), Budget Information 1994-95, Budget Paper No. 2, Sydney.

New South Wales Treasury (1994), A Sacial Program Policy for NSW Govenument Trading Euterprises, Sydney.

Niskanen, W. (1971), Bureaucracy and Representative Govenment, Aldine, Chicago.

Social Welfare Policy Secretaiuat (SWPS) (1984), Pensioner Fringe Benefits: Their Range, Cost and Value, AGPS, Canberra.

Stigler, G. (1975), The Citizen and the State: Essays on Regulation, University of Chicago Press, Chicago.

The author would like to thank the referees and the Editor for their comments on a previous version of this article. The views put forward in this article are solely his. 